\title{
Meta-Analysis of Microsomal Epoxide Hydrolase Gene Polymorphism and Risk of Hepatocellular Carcinoma
}

\author{
Jian-Hong Zhong ${ }^{19}$, Bang-De Xiang ${ }^{19}$, Liang Ma ${ }^{1}$, Xue-Mei You ${ }^{1}$, Le-Qun Li $^{1 *}$, Gui-Sheng Xie ${ }^{2}$ \\ 1 Hepatobiliary Surgery Department, Tumor Hospital of Guangxi Medical University, Nanning, People's Republic of China, 2 General Surgery Department, The Third
} Affiliated Hospital of Guangxi Medical University, Nanning, People's Republic of China

\begin{abstract}
Background: Hepatocarcinogenesis is a complex process that may be influenced by many factors, including polymorphism in microsomal epoxide hydrolase $(\mathrm{mEH})$. Previous work suggests an association between the Tyr113His and His139Arg mEH polymorphisms and susceptibility to hepatocellular carcinoma (HCC), but the results have been inconsistent.

Methods: PubMed, EMBASE, Google Scholar and the Chinese National Knowledge Infrastructure databases were systematically searched to identify relevant studies. A meta-analysis was performed to examine the association between Tyr113His and His139Arg mEH polymorphism and susceptibility to HCC. Odds ratios (ORs) and 95\% confidence intervals (95\% Cls) were calculated.

Results: Eleven studies were included in the meta-analysis, involving 1,696 HCC cases and 3,600 controls. The $113 \mathrm{His}-\mathrm{mEH}$ allele was significantly associated with increased risk of HCC based on allelic contrast $(\mathrm{OR}=1.35,95 \% \mathrm{Cl}=1.04-1.75$, $\mathrm{p}=0.02)$, homozygote comparison $(\mathrm{OR}=1.65,95 \% \mathrm{Cl}=1.07-2.54, \mathrm{p}=0.02)$ and a recessive genetic model $(\mathrm{OR}=1.54,95 \%$ $\mathrm{Cl}=1.21-1.96, \mathrm{p}<0.001)$, while individuals carrying the Arg139Arg mEH genotype had no association with increased or decreased risk of HCC.

Conclusion: The 113His- allele polymorphism in $\mathrm{mEH}$ may be a risk factor for hepatocarcinogenesis, while the mEH 139Argallele may not be a risk or protective factor. There is substantial evidence that $\mathrm{mEH}$ polymorphisms interact synergistically with other genes and the environment to modulate risk of HCC. Further large and well-designed studies are needed to confirm these conclusions.
\end{abstract}

Citation: Zhong J-H, Xiang B-D, Ma L, You X-M, Li L-Q, et al. (2013) Meta-Analysis of Microsomal Epoxide Hydrolase Gene Polymorphism and Risk of Hepatocellular Carcinoma. PLoS ONE 8(2): e57064. doi:10.1371/journal.pone.0057064

Editor: Erica Villa, University of Modena \& Reggio Emilia, Italy

Received September 20, 2012; Accepted January 17, 2013; Published February 25, 2013

Copyright: (c) 2013 Zhong et al. This is an open-access article distributed under the terms of the Creative Commons Attribution License, which permits unrestricted use, distribution, and reproduction in any medium, provided the original author and source are credited.

Funding: This work was supported by the grants from the National Natural Science Foundation of China (Project No: 81160262/H1602) and Guangxi Natural Science Foundation (Project No: 2011GXNSFD018032) to LL, and the Self-raised Scientific Research Fund of the Ministry of Health of Guangxi Province (Project No: Z2012345) to JHZ. The funders had no role in study design, data collection and analysis, decision to publish, or preparation of the manuscript.

Competing Interests: The authors have declared that no competing interests exist.

*E-mail: xitongpingjia@163.com

9 These authors contributed equally to this work.

\section{Introduction}

As the most frequent primary cancer of the liver, hepatocellular carcinoma (HCG) is a significant cause of cancer morbidity and mortality worldwide, and treatment options are limited. The estimated incidence of new HCC cases each year is more than 0.5 million [1]. Sub-Saharan Africa and Southeast Asia are the regions with highest incidence of HCG (>20 per 100,000 people) [2]. Epidemiologically, HCC is strongly associated with hepatitis B virus $(\mathrm{HBV})$ and hepatitis $\mathrm{C}$ virus (HCV) infection, alcohol consumption, and aflatoxin B1 (AFB) contamination of foodstuffs, among other factors [3-4]. In developing countries, AFB together with chronic HBV infection contributes to the high incidence of HCC. However, not all individuals with these factors appear to have the same risk of developing HCG. HCG exhibits a high degree of genetic heterogeneity: multiple molecular pathways may give rise to subsets of hepatocellular neoplasms.

HCG pathogenesis remains incompletely understood. It is known to involve chronic inflammation, hepatocyte hyperplasia and ultimately malignant transformation [5]. Current thinking is that HCC is a multifactorial disease, the etiology of which involves various host and environmental factors. Moreover, host and environmental factors may interact synergistically in HCC pathogenesis and progression.

The liver has a complex detoxification system. In this complex system, several enzymes participate in the metabolism of both exogenous and endogenous metabolites produced by oxidative stress in chronic infections, such as HBV and HCV infections. The genes encoding these enzymes are polymorphic, and the variant sequences lead to enzymes with altered activity. Any genetic defect in these xenobiotic-metabolizing enzymes may lead to accumulation of viral integration products and xenobiotics. This should increase the risk of liver diseases, such as cirrhosis and HCG.

Microsomal epoxide hydrolase $(\mathrm{mEH})$ is one of these enzymes. As a phase II metabolic enzyme, $\mathrm{mEH}$ is involved in the hydrolysis of various epoxides and deleterious chemical epoxide intermediates generated by phase I oxidation reactions 
[6-7]. Since epoxides are highly reactive oxidative metabolites, $\mathrm{mEH}$ is considered to act on the most toxicologically active forms of drugs and environmental chemicals. Despite its important protective function, its net effects on the body can be complex, since it plays a dual role of procarcinogen detoxifier and activator [8].

The gene encoding $\mathrm{mEH}$ consists of nine exons and eight introns. Two relatively frequent single nucleotide polymorphisms occur in the coding region: Tyr113His in exon 3 and His139Arg in exon 4. These polymorphisms modify protein stability: Tyr113His decreases enzyme activity, while His139Arg increases it [9].

In 1995, Mcglynn and coworkers [10] explored the association between $\mathrm{mEH}$ polymorphism and risk of HCG. They found that the Tyr $113 \mathrm{His} \mathrm{mEH}$ gene polymorphism is associated with risk of developing HCG. The study also found a synergistic increase in the risk of HCG when $\mathrm{HBV}$ infection and susceptible genotype occurred together [10]. More recently, epidemiological studies have evaluated the association between the Tyr113His and His 139Arg mEH gene polymorphisms and risk of HCC in diverse ethnicities, with inconsistent results [11-20]. Some of these studies also revealed synergistic gene-gene [13,17-19] and gene-environment $[10,16,20]$ interactions. A single case-control study may fail to completely demonstrate these complicated genetic relationships because of small sample size. In order to provide stronger evidence of the effects of these two mEH polymorphisms on HCC risk, we carried out a meta-analysis by combining data from numerous published studies.

\section{Methods}

\section{Search Strategy}

All case-control studies of mEH polymorphism and HCG risk published up to August 31, 2012 were identified through systematic searches in PubMed, EMBASE, Google Scholar and the Chinese National Knowledge Infrastructure (CNKI) databases using English and Chinese. The search terms used were: $m E H$; HYL1; EPHX; microsomal epoxide hydrolase; these four terms in combination with polymorphism, variation, genotype, genetic and mutation; and all of the above terms in combination with hepatocellular carcinoma, HCC, liver cancer, liver tumor, liver neoplasms and hepatic tumor. The references of each article identified were also manually searched to identify additional relevant publications.

\section{Inclusion Criteria}

A study was included in the meta-analysis if it satisfied the following criteria: (a) it assessed the association between HCC and the Tyr113His and His139Arg mEH gene polymorphisms, (b) it used a case-control design, and (c) it provided sufficient published data for estimating an odds ratio (OR) with a 95\% confidence interval $(95 \%$ CI $)$. In the case of multiple studies based on the same population, we selected the study with the largest number of participants.

\section{Data Extraction}

Literature searches and identification of eligible articles based on the inclusion criteria were carried out independently by two authors (JHZ and BDX). These authors independently extracted the following data: first author's name, year of publication, ethnicity or country, source of controls (hospital- or populationbased), exon number, numbers and genotypes of cases and controls, and Hardy-Weinberg equilibrium (HWE) of controls. Discrepancies were resolved by consensus.

\section{Statistical Methods}

The unadjusted OR with 95\% CI was used to assess the strength of the association between the Tyr113His and His139Arg $\mathrm{mEH}$ polymorphisms and HCG risk based on the genotype frequencies in cases and controls. Subgroup analysis stratified by ethnicity was performed. Ethnicity was categorized as Chinese and mixed. The meta-analysis examined the association of different genotypes at Tyr113His mEH with HCC risk by comparing the 113 Tyr allele (113T-allele) with the 113 His allele (113H-allele), the homozygous comparison (His113His vs. Tyr113Tyr), and recessive and dominant genetic model. The same approach was used to examine the association of Hisl39Arg mEH and HCC risk.

All statistical tests for this meta-analysis were performed using RevMan 5.0 and Stata 11.0 softwares. Fixed-effect and randomeffect models were used to calculate a pooled OR. The statistical significance of the pooled OR was determined using the Z-test, and $\mathrm{P}<0.05$ was considered statistically significant. The assumption of heterogeneity was evaluated by applying a chi square-based Q-test among the studies. P $>0.10$ for the Q-test indicates a lack of statistical heterogeneity, suggesting the variability in effect sizes is larger than that expected from chance alone [21]. In these cases, a pooled OR was calculated for each study using the fixed-effects model. Otherwise, the random-effect model was used. To assess the reliability of the outcomes in the meta-analysis, a sensitivity analysis was performed by excluding one study at a time. Smallstudy bias was assessed by Harbord's modified test [22]. HWE in the control group was assessed using the asymptotic test, with $\mathrm{P}<0.05$ considered significant.

\section{Results}

\section{Description of Studies}

A total of 223 potentially relevant publications up to August 31, 2012 were systematically identified through PubMed, EMBASE, Google Scholar and CNKI. After screening the title and/or abstracts, $174(78 \%)$ were excluded because they did not satisfy the inclusion criteria. An additional 36 publications were excluded because they did not examine Tyr113His and His139Arg mEH polymorphisms or they were review articles. Three publications $[19,23,24]$ were based on the same participants with HCC, so they were considered as one study. In the end, 11 studies [10-20] were included in this meta-analysis based on our search strategy and inclusion criteria (Fig. 1).

We established a database according to the information extracted from each article. Detailed characteristics of the 11 studies are listed in Tables 1 and 2. Overall, 1,696 HCC cases and 3,600 controls were retrieved. Six of the studies involved Chinese subjects $[10-11,15-16,18,20]$. Of these, three studies involving 232 cases and 322 controls were published in Chinese, while the other three involving 540 cases and 1021 controls were published in English. The populations of the remaining five studies came from the UK [12], Sudan [13], Italy [14], Gambia [17], and India [19]. All studies had a case-control design. Three studies $[12,14,19]$ included a control population with liver disease (hospital-based control). These three studies [12,14,19] involved 202 HCC cases and 536 controls. The number of populationbased controls was 3,064. However, some of the population-based controls (health population) had liver disease. Therefore, subgroup analysis by source of controls was not conducted. Of the total number of 5,296 subjects considered in the meta-analysis, at least 2,000 (37.8\%) had one or more of the following: alcoholic liver disease, HBV or HCV infection, and cirrhosis. Most studies did not report detailed data on the percentages of their subjects with 

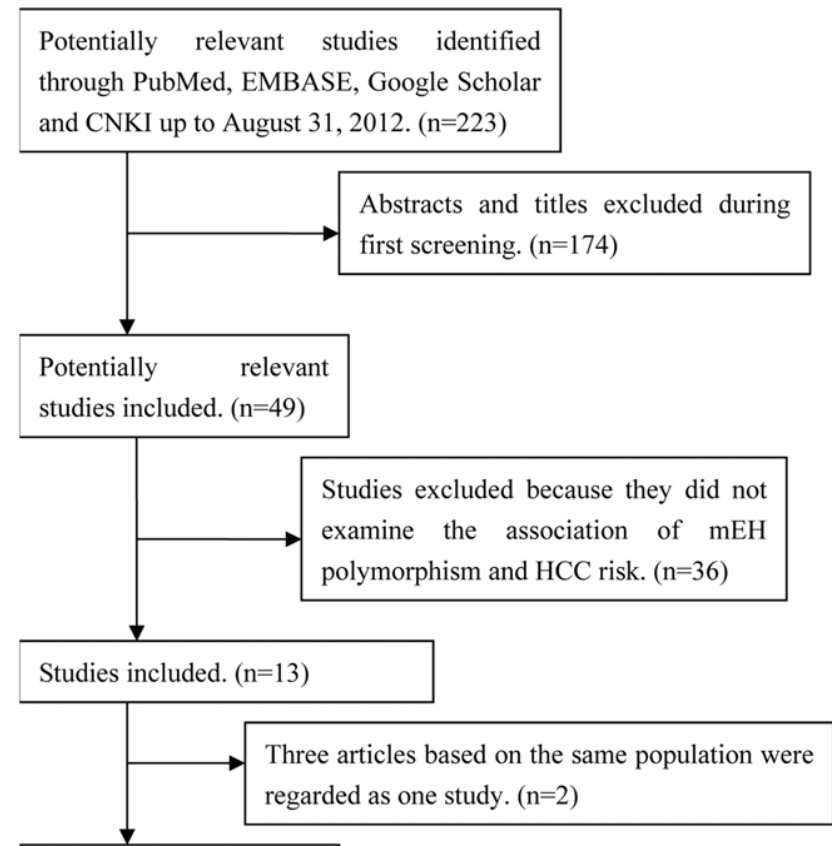

Studies included in the meta-analysis. $(\mathrm{n}=11)$

Figure 1. Flow chart of study selection. CNKI, Chinese National Knowledge Infrastructure; $\mathrm{mEH}$, microsomal epoxide hydrolase; HCC, hepatocellular carcinoma.

doi:10.1371/journal.pone.0057064.g001

these background conditions. Therefore we could not define subgroups for meta-analysis based on liver disease, $\mathrm{HBV} / \mathrm{HCV}$ infection or cirrhosis status.

All 11 studies described the Tyrl13His polymorphism; however, only 6 studies [12-16,19] described the His139Arg polymorphism. The distribution of genotypes among controls did not show HWE in several studies [10-11,13-15,17-18,20] (Tables 1 and 2).

\section{Test of Heterogeneity}

Table 3 shows the relationship between the Tyrl13His mEH polymorphism and HCG risk. The statistical heterogeneity of Tyr113His mEH allelic contrast, homozygote comparison, and dominant and recessive genetic models was analyzed for all 11 studies. Statistically significant heterogeneity was observed in all studies except for the recessive genetic model for the Chinese subgroup. Therefore, random-effect models were used to analyze the OR.

For the heterogeneity of Hisl39Arg mEH, statistically significant heterogeneity was observed for allelic contrast $(P=0.003$, $\left.I^{2}=72 \%\right)$ and the dominant genetic model comparison $(P<0.001$, $\left.I^{2}=76 \%\right)$. However, no heterogeneity was found between studies for the homozygote comparison and recessive genetic model comparison $\left(I^{2}=0 \%\right)$ (Table S1).

\section{Quantitative Data Synthesis}

Table 3 shows the summary ORs for the Tyrl13His mEH polymorphism and HCC risk on the basis of 1,696 HCC cases and 3,600 controls. We observed an association between Tyr 13 His $\mathrm{mEH}$ genotype and $\mathrm{HCC}$ risk in the total population based on all 11 studies. Given the ethnic differences in the allele frequency of this sequence variant, we evaluated the effect of the Tyr113His $\mathrm{mEH}$ polymorphism separately in Chinese and in other populations. Given that not only some of the healthy population in the control arm had liver disease, but also most studies did not report detailed data on the percentages of their subjects with these background conditions, we did not compute overall ORs stratified by source of control.

Table 1. Main characteristics of studies about $\mathrm{mEH}$ exon 3 polymorphism included in the meta-analysis.

\begin{tabular}{|c|c|c|c|c|c|c|c|c|c|c|c|}
\hline \multirow[t]{2}{*}{ Study } & \multirow[t]{2}{*}{ Country } & \multirow[t]{2}{*}{$\begin{array}{l}\text { Source of } \\
\text { control }\end{array}$} & \multirow[t]{2}{*}{$\mathbf{P}_{\text {HWE }}$} & \multirow[t]{2}{*}{$\begin{array}{l}\text { Prequency of }_{\text {F }} \\
113 \text { His-allele }\end{array}$} & \multirow[t]{2}{*}{$\begin{array}{l}\text { Cases/ } \\
\text { Controls }\end{array}$} & \multicolumn{3}{|c|}{ No. of cases } & \multicolumn{3}{|c|}{ No. of controls } \\
\hline & & & & & & risk & heterozygous & non-risk & risk & heterozygous & non-risk \\
\hline Mcglynn $1995^{10}$ & $\begin{array}{l}\text { Chinese } \\
\text { and Ghana }\end{array}$ & Healthy§ & $<0.001$ & $<0.001$ & $52 / 165$ & 29 & 18 & 5 & 44 & 57 & 64 \\
\hline Shen $1997^{11}$ & Chinese & Healthy§ & 0.001 & 0.03 & $39 / 67$ & 21 & 13 & 4 & 27 & 20 & 20 \\
\hline Wong $2000^{12}$ & UK & $\begin{array}{l}\text { Healthy } \\
\text { and ALD }\end{array}$ & 0.087 & 0.42 & $46 / 264$ & 5 & 23 & 18 & 20 & 127 & 117 \\
\hline Tiemersma $2001^{13}$ & Sudan & Healthy§ & 0.007 & 0.21 & $112 / 194$ & 14 & 28 & 68 & 15 & 50 & 128 \\
\hline Sonzogni $2002^{14}$ & Italy & $\begin{array}{l}\text { Healthy, } \mathrm{HC} \text {, } \\
\mathrm{CH} \text {, and } \\
\text { Cirrhosis }\end{array}$ & 0.0258 & $<0.001$ & $93 / 400$ & 26 & 38 & 29 & 57 & 159 & 184 \\
\hline McGlynn $2003^{15}$ & Chinese & Healthy§ & $<0.001$ & 0.86 & $231 / 256$ & 118 & 49 & 64 & 113 & 87 & 56 \\
\hline Cao $2004^{16}$ & Chinese & Healthy§ & 0.120 & 0.01 & $88 / 104$ & 35 & 35 & 18 & 27 & 44 & 33 \\
\hline Kirk $2005^{17}$ & Gambia & Healthy§ & 0.001 & 0.49 & $195 / 351$ & 11 & 46 & 138 & 18 & 77 & 256 \\
\hline Long $2006^{18}$ & Chinese & Healthy§ & $<0.001$ & $<0.001$ & $257 / 649$ & 91 & 70 & 96 & 168 & 100 & 381 \\
\hline Kiran $2008^{19}$ & Indian & $\begin{array}{l}\text { Healthy } \\
\text { and CH }\end{array}$ & 0.280 & 0.005 & $63 / 343$ & 12 & 25 & 26 & 100 & 161 & 82 \\
\hline He $2008^{20}$ & Chinese & Healthy§ & 0.001 & 0.97 & $105 / 151$ & 53 & 23 & 29 & 67 & 52 & 32 \\
\hline
\end{tabular}

Note: ALD, alcoholic liver disease; $\mathrm{CH}$, Chronic hepatitis; $\mathrm{HC}$, hepatitis carrier; $\mathrm{HWE}$, Hardy-Weinberg equilibrium; $\S$, some were carriers of hepatitis $\mathrm{B}$ and/or $\mathrm{C}$ virus. doi:10.1371/journal.pone.0057064.t001 
Table 2. Main characteristics of studies about $\mathrm{mEH}$ exon 4 polymorphism included in the meta-analysis.

\begin{tabular}{|c|c|c|c|c|c|c|c|c|c|c|c|}
\hline \multirow[t]{2}{*}{ Study } & \multirow[t]{2}{*}{ Country } & \multirow[t]{2}{*}{$\begin{array}{l}\text { Source of } \\
\text { control }\end{array}$} & \multirow[t]{2}{*}{$\mathbf{P}_{\text {HWE }}$} & \multirow[t]{2}{*}{$\begin{array}{l}P_{\text {Frequency o }} \\
\text { 139Arg-allele }\end{array}$} & \multirow[t]{2}{*}{$\begin{array}{l}\text { f Cases/ } \\
\text { Controls }\end{array}$} & \multicolumn{3}{|c|}{ No. of cases } & \multicolumn{3}{|c|}{ No. of controls } \\
\hline & & & & & & risk & heterozygous & non-risk & risk & heterozygous & non-risk \\
\hline Wong $2000^{12}$ & UK & $\begin{array}{l}\text { Healthy } \\
\text { and ALD }\end{array}$ & 0.831 & 0.91 & $39 / 264$ & 1 & 12 & 26 & 7 & 78 & 179 \\
\hline Tiemersma $2001^{13}$ & Sudan & Healthy§ & 0.847 & 0.54 & $112 / 194$ & 3 & 44 & 63 & 13 & 69 & 102 \\
\hline Sonzogni $2002^{14}$ & Italy & $\begin{array}{l}\text { Healthy, } \mathrm{HC}, \mathrm{CH} \text {, } \\
\text { and Cirrhosis }\end{array}$ & 0.876 & 0.22 & $93 / 400$ & 4 & 22 & 67 & 15 & 131 & 254 \\
\hline McGlynn $2003^{15}$ & Chinese & Healthy§ & 0.074 & $<0.001$ & $231 / 256$ & 3 & 31 & 197 & 3 & 79 & 174 \\
\hline Cao $2004^{16}$ & Chinese & Healthy§ & 0.296 & 0.02 & $88 / 104$ & 1 & 12 & 75 & 1 & 32 & 71 \\
\hline Kiran $2008^{19}$ & Indian & $\begin{array}{l}\text { Healthy } \\
\text { and } \mathrm{CH}\end{array}$ & 0.221 & 0.37 & $63 / 343$ & 16 & 31 & 16 & 64 & 155 & 124 \\
\hline
\end{tabular}

Note: ALD, alcoholic liver disease; $\mathrm{CH}$, Chronic hepatitis; $\mathrm{HC}$, hepatitis carrier; $\mathrm{HWE}$, Hardy-Weinberg equilibrium; $\S$, some were carriers of hepatitis $\mathrm{B}$ and/or $\mathrm{C}$ virus. doi:10.1371/journal.pone.0057064.t002

\section{Total Population}

Calculation of overall OR in the total population using the random-effect model showed that the 113His- allele was strongly associated with increased risk of HCG based on allelic contrast $\left(\mathrm{OR}=1.35,95 \%\right.$ CI $\left.=1.04-1.75, P=0.02 ; I^{2}=83 \%\right) \quad($ Fig. 2), homozygote comparison $(\mathrm{OR}=1.65, \quad 95 \% \quad \mathrm{CI}=1.07-2.54$, $\left.P=0.02 ; I^{2}=78 \%\right)$ and the recessive genetic model $(\mathrm{OR}=1.54$, $95 \% \mathrm{CI}=1.21-1.96, P<0.001 ; I^{2}=48 \%$ ). Association of the $\mathrm{mEH}$ with $\mathrm{HCC}$ risk was not observed in the total population using the dominant genetic model $(\mathrm{OR}=0.73,95 \%$ CI $=0.50-1.07$, $\left.P=0.11 ; I^{2}=83 \%\right)$.

For the His139Arg mEH polymorphism and HCC risk, no statistically significant effect was observed based on allelic contrast $\left(\mathrm{OR}=0.83,95 \% \mathrm{CI}=0.59-1.18, P=0.30 ; I^{2}=72 \%\right)$, homozygote comparison $(\mathrm{OR}=1.09,95 \% \quad \mathrm{CI}=0.67-1.78, \quad P=0.74$;
$\left.I^{2}=0 \%\right)$, dominant genetic model comparison $(\mathrm{OR}=1.40,95 \%$ $\mathrm{CI}=0.88-2.23, P=0.15 ; I^{2}=76 \%$ ) or recessive genetic model comparison $\left(\mathrm{OR}=1.08,95 \% \mathrm{CI}=0.68-1.70, P=0.75 ; I^{2}=0 \%\right)$. Because the populations in the six studies reporting the His $139 \mathrm{Arg}$ polymorphism were from non-overlapping ethnicities, we did not conduct subgroup analysis by ethnicity.

\section{Ethnicity}

Chinese population. After stratification for ethnicity, we observed that in the Chinese population, the 113His- allele, homozygote variant and recessive genetic model were significantly associated with increased risk of HCG (113His- allele, OR $=1.62$, 95\% CI $=1.15-2.28, P=0.006 ;$ homozygote, $\mathrm{OR}=1.79,95 \%$ $\mathrm{CI}=1.08-2.97, \quad P=0.002 ;$ recessive model, $\mathrm{OR}=1.52, \quad 95 \%$ $\mathrm{CI}=1.26-1.83, P<0.001)$. However, this association was not

Table 3. Overall and stratified meta-analyses of the association between $\mathrm{mEH}$ polymorphism Tyr113His and risk of hepatocellular carcinoma.

\begin{tabular}{|c|c|c|c|c|c|c|}
\hline \multirow[t]{2}{*}{ Genotype comparison } & \multirow[t]{2}{*}{ OR $[95 \% \mathrm{CI}]$} & \multirow[t]{2}{*}{ Z (P value) } & \multicolumn{3}{|c|}{ Heterogeneity of study design } & \multirow[t]{2}{*}{ Analysis mode } \\
\hline & & & $\chi^{2}$ & df ( $P$ value) & $\mathbf{I}^{2}$ & \\
\hline \multicolumn{7}{|c|}{ Total (1696 cases, 3600 controls) } \\
\hline 113His-allele vs. 113Tyr-allele & $1.35[1.04,1.75]$ & $2.28(0.02)$ & 58.56 & $10(<0.001)$ & $83 \%$ & Random \\
\hline His/His vs. Tyr/Tyr & $1.65[1.07,2.54]$ & $2.28(0.02)$ & 44.87 & $10(<0.001)$ & $78 \%$ & Random \\
\hline His/His vs. Tyr/His+Tyr/Tyr & $1.54[1.21,1.96]$ & $3.51(<0.001)$ & 19.34 & $10(0.04)$ & $48 \%$ & Random \\
\hline Tyr/Tyr vs. His/His+Tyr/His & $0.73[0.50,1.07]$ & $1.62(0.11)$ & 58.06 & $10(<0.001)$ & $83 \%$ & Random \\
\hline \multicolumn{7}{|l|}{ Ethnic subgroups } \\
\hline \multicolumn{7}{|c|}{ Chinese (1070 cases, 1838 controls) } \\
\hline 113His-allele vs. 113Tyr-allele & $1.62[1.15,2.28]$ & $2.76(0.006)$ & 28.65 & $5(<0.001)$ & $83 \%$ & Random \\
\hline His/His vs. Tyr/Tyr & $1.79[1.08,2.97]$ & $2.25(0.02)$ & 19.27 & $5(0.002)$ & $74 \%$ & Random \\
\hline His/His vs. Tyr/His+Tyr/Tyr & $1.52[1.26,1.83]$ & $4.40(<0.001)$ & 2.48 & $5(0.78)$ & $0 \%$ & Fixed \\
\hline Tyr/Tyr vs. His/His+Tyr/His & $0.63[0.35,1.13]$ & $1.54(0.12)$ & 32.43 & $5(<0.001)$ & $85 \%$ & Random \\
\hline \multicolumn{7}{|c|}{ Others (UK, Sudan, Italy, Gambia, and India) (577 cases, 1762 controls) } \\
\hline 113His-allele vs. 113Tyr-allele & $1.07[0.76,1.51]$ & $0.39(0.70)$ & 16.69 & $4(0.002)$ & $76 \%$ & Random \\
\hline His/His vs. Tyr/Tyr & $1.29[0.61,2.71]$ & $0.67(0.50)$ & 18.11 & $4(0.001)$ & $78 \%$ & Random \\
\hline His/His vs. Tyr/His+Tyr/Tyr & $1.31[0.76,2.26]$ & $0.97(0.33)$ & 11.11 & $4(0.03)$ & $64 \%$ & Random \\
\hline Tyr/Tyr vs. His/His+Tyr/His & $0.92[0.59,1.42]$ & $0.39(0.70)$ & 15.13 & $4(0.004)$ & $74 \%$ & Random \\
\hline
\end{tabular}




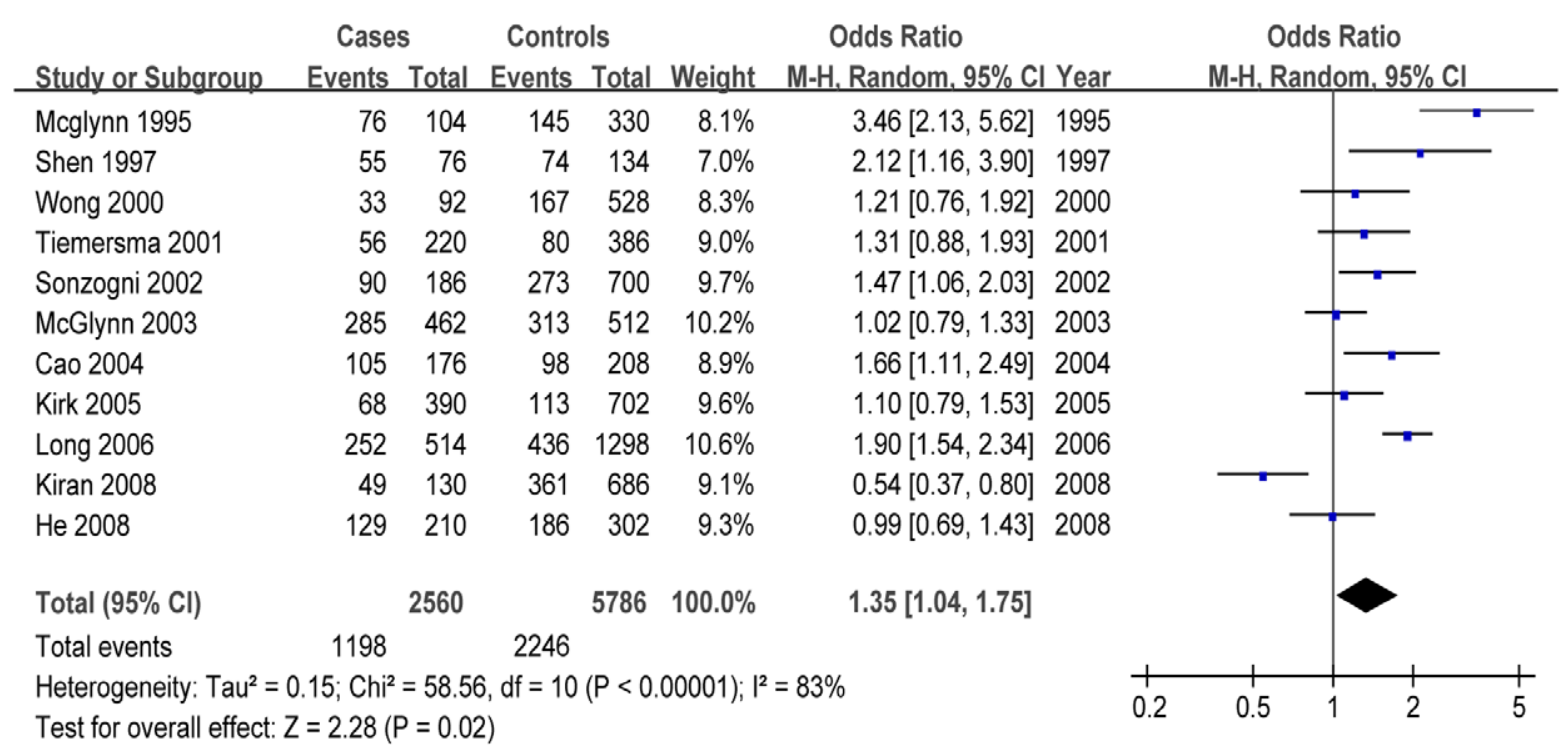

Figure 2. Forest plots describing the association of $\mathrm{mEH}$ polymorphism Tyr113His with hepatocellular carcinoma (113His- vs. 113Tyr-).

doi:10.1371/journal.pone.0057064.g002

observed in the dominant genetic model $(\mathrm{OR}=0.63,95 \%$ $\mathrm{CI}=0.35-1.13, P=0.12)$.

Mixed population. Analysis of the mixed population in five studies $[12-16,19]$ revealed that the 113 His- allele, homozygote variant and recessive genetic model were not significantly associated with increased risk of $\mathrm{HCC}$ using a random-effect model $(113 \mathrm{His}$ - allele, $\mathrm{OR}=1.07,95 \% \mathrm{CI}=0.76-1.51, P=0.70$; homozygote, $\mathrm{OR}=1.29,95 \% \mathrm{CI}=0.61-2.71, P=0.50$; recessive model, $\mathrm{OR}=1.31,95 \% \mathrm{CI}=0.76-2.26, P=0.33)$. Similarly, the dominant Tyr113His genotype was not associated with HCG risk.

\section{Sensitivity Analysis}

In the allele contrast, the result was altered after excluding the study by Mcglynn and coworkers [10], with OR of 1.24 (95\% CI 0.98 to $1.58, P=0.08)$. In the recessive genetic model contrast, the results were not altered after excluding studies one by one. However, in the dominant genetic model contrast, the result was statistically significant after excluding the study by Kiran et al. [19], with OR of 0.66 (95\% CI 0.46 to $0.94, P=0.02)$. Therefore, the results should be interpreted with caution. For the His139Arg mEH polymorphism and HCG risk, the results were not altered based on allelic contrast, dominant or recessive genetic model comparison.

\section{Small-study Bias}

Harbord's modified test was prepared for the 11 studies [10-20] to assess the small-study bias for reported comparisons of $\mathrm{mEH}$ allele contrast and HCC. The P value is 0.913 , suggesting the absence of small-study bias (Fig. 3).

\section{Discussion}

HCG involves complex, multistep and heterogeneous malignant tumorigenesis. The pathogenesis of HCG involves host and environmental factors, as well as modulation of molecular signaling pathways implicated in malignant transformation of hepatocytes and tumor progression [25]. Polymorphism in the $\mathrm{mEH}$ gene has been associated with risk of various malignancies
[26-28], including HCG [14]. Two relatively common genetic polymorphisms occur in the mEH gene: Tyr113His in exon 3 and His 139Arg in exon 4. The $\mathrm{C}$ to $\mathrm{T}$ transition in the Tyrl13His polymorphism eliminates an EcoRV restriction site, while an A to $\mathrm{G}$ transition in the His139Arg polymorphism creates an Rsal cleavage site [9]. The Tyr113His polymorphism decreases $\mathrm{mEH}$ activity by $40-50 \%$, while the His 139 Arg polymorphism increases it by $25 \%$ [9].

Some studies reported an association between the Tyrl13His polymorphism and HCG risk, while others found no such association. The most likely reason for the inconsistencies among these studies is that they are single case-control studies with small sample sizes. To help resolve these conflicting results using a larger sample size, we conducted meta-analysis of published studies. Our results for the total population suggest an increased HCG risk for subjects carrying the Tyr113His mEH genotype. Our approach also allowed us to look for potential ethnic differences in the association. Analysis of ethnic subgroups showed that in the Chinese population, the $113 \mathrm{His}$ - allele was strongly associated with increased risk of HCC based on allelic contrast, homozygote comparison and the recessive genetic model. However, no association was observed for other populations (UK, Sudan, Italy, Gambia, and India). Six studies [12-16,19] reported the association of His 139Arg mEH polymorphism and HCC risk. The results of the present meta-analysis revealed that the 139Argallele is not associated with increased or decreased risk of HCC.

The clinical significance of $\mathrm{mEH}$ polymorphisms extends beyond HCC. Polymorphisms in this gene have been reported to be susceptibility factors for several human diseases, such as type 2 diabetes mellitus [29], alcohol dependence [30], and chronic obstructive pulmonary disease [31]. In fact, two earlier metaanalyses [32-33] suggested a potential protective effect of the Tyr113His polymorphism and a potential harmful effect of the His 139Arg polymorphism on lung cancer. While some studies have reported that $\mathrm{mEH}$ polymorphisms do not affect susceptibility to esophageal carcinoma [34] or colorectal cancer [35-36], other studies [27,37] have shown that the mEH $113 \mathrm{His}$ allele is associated with increased risk of ovarian cancer. 


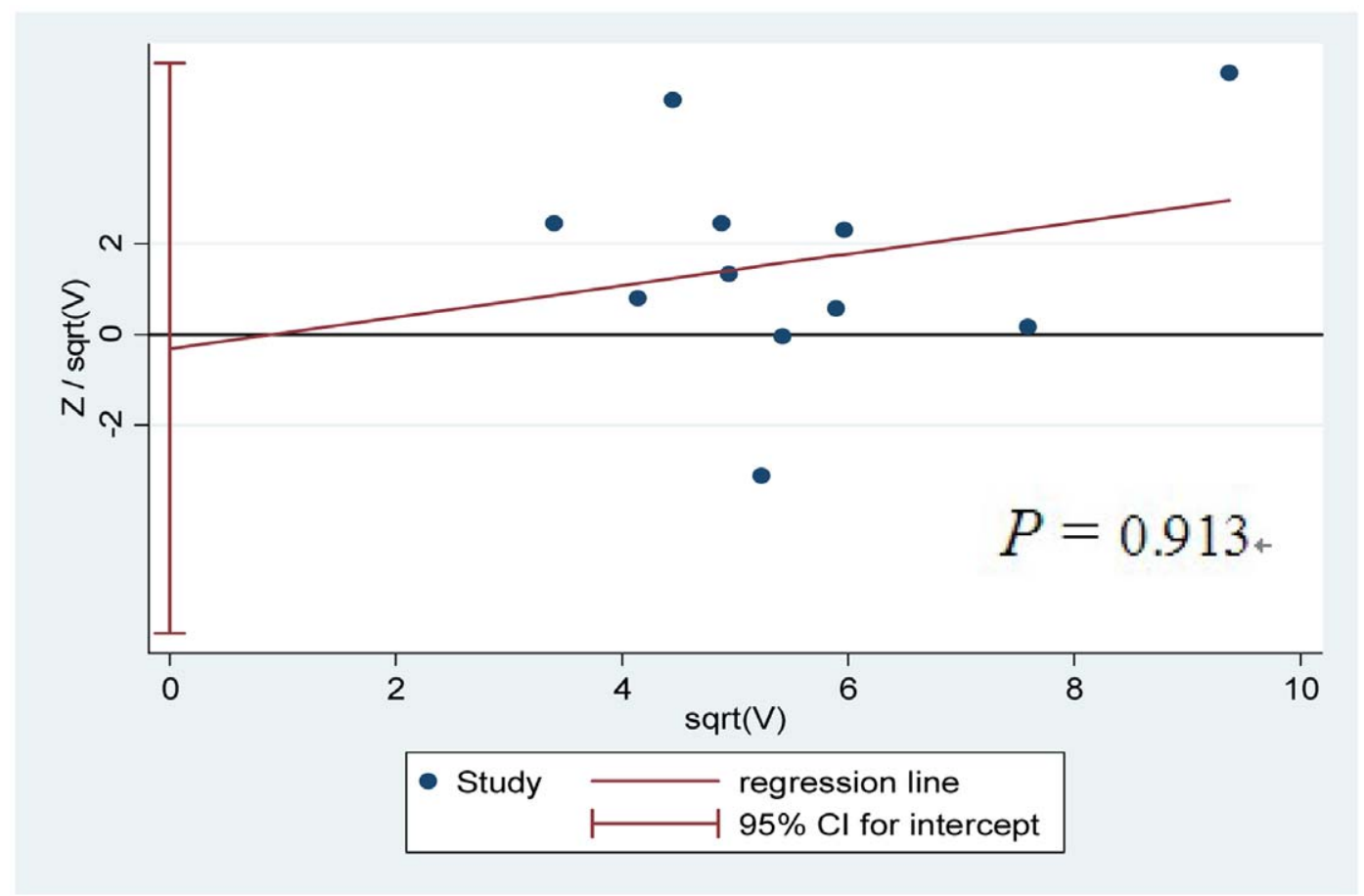

Figure 3. Small-study biases about the allele contrast (113His- vs. 113Tyr-) of mEH polymorphism with hepatocellular carcinoma. doi:10.1371/journal.pone.0057064.g003

Several studies in our meta-analysis indicate that $\mathrm{mEH}$ polymorphisms can interact with environmental factors to module HCG risk (Table 4) $[10,16,18,20]$. Two such synergistic geneenvironment interactions are that smoking populations with $\mathrm{mEH}$ polymorphism are at increased risk of $\mathrm{HCG}$ [16,20], while a synergistic effect of smoking, drinking, and $\mathrm{mEH}$ polymorphism was observed in $\mathrm{HBV}$-infected individuals [20]. Moreover, the association between mEH polymorphism and HCG depended on HBV status, suggesting a synergistic increase in risk of HCG when HBV infection and susceptible genotype occur together [10,18].

Table 4. Studies reporting gene-gene or gene-environment interactions.
Our meta-analysis also revealed gene-gene interactions between the $\mathrm{mEH}$ polymorphisms and genotypes associated with elevated risk of AFB toxicity. Individuals with a greater number of suspected AFB-related high-risk genotypes (GSTM1-null, mEH$\mathrm{YH} / \mathrm{HH}, \mathrm{XRCCl-AG/GG)} \mathrm{faced} \mathrm{a} \mathrm{greater} \mathrm{risk} \mathrm{of} \mathrm{HCG} \mathrm{than}$ those without any high-risk genotypes, especially among individuals with higher AFB exposure [13,17-19]. These results demonstrate that the etiology of HCC is complex and involves host and environmental factors that may interact synergistically.

The $113 \mathrm{His}$ codon variant is relatively common in the $\mathrm{mEH}$ gene. However, the allele frequency differs significantly among

\begin{tabular}{|c|c|c|}
\hline Study & $\begin{array}{l}\text { Percent of liver } \\
\text { disease cases with } \\
\text { the indicated } \\
\text { infection }\end{array}$ & Gene-gene or gene-environment interactions reported \\
\hline Mcglynn 1995 (10) & $77 \% \mathrm{HBV}$ & The relationship of $m E H$ polymorphism to HCC depended on HBV status, suggesting a synergistic effect. \\
\hline Tiemersma 2001 (13) & $41 \% \mathrm{HBV}, 12 \% \mathrm{HCV}$ & $\begin{array}{l}\text { Individuals with GSTM1 or GSTT1 non-null genotypes in combination with the } 113 \mathrm{HH} \text { and } 139 \mathrm{HH} \mathrm{mEH} \text { genotypes were } \\
\text { at increased risk of HCC. }\end{array}$ \\
\hline Cao 2004 (16) & NR & Smokers with a $\mathrm{mEH}$ polymorphism were at increased risk of HCC. \\
\hline Kirk 2005 (17) & $61 \% \mathrm{HBV}, 19 \% \mathrm{HCV}$ & $\begin{array}{l}\text { Individuals who had all three suspected AFB-related high-risk genotypes (GSTM1-null, } m E H-H Y / H H \text {, and } X R C C 1-A G / G G \text { ) } \\
\text { had, } 15 \text {-fold higher risk of HCC. }\end{array}$ \\
\hline Long 2006 (18) & $84 \% \mathrm{HBV}$ & $\begin{array}{l}\text { Individuals with more high-risk genotypes (GSTM1-null, } m E H-H Y / H H, X R C C 1-A G / G G \text { ) faced a greater risk of HCC than } \\
\text { those individuals without any high-risk genotype, especially among individuals with higher AFB exposure. }\end{array}$ \\
\hline Kiran 2008 (19) & $65 \% \mathrm{HBV}, 35 \% \mathrm{HCV}$ & $\begin{array}{l}\text { Individuals with GSTM1 or GSTT1 non-null genotypes in combination with the } \mathrm{mEH} 113 \mathrm{HH} \text { and } 139 \mathrm{HH} \text { genotypes were } \\
\text { at increased risk of HCC. }\end{array}$ \\
\hline He 2008 (20) & $74 \% \mathrm{HBV}$ & $\begin{array}{l}\text { Smokers with a } m E H \text { polymorphism were at increased risk of } \mathrm{HCC} \text {; a synergistic effect of smoking, drinking, and } m E H \\
\text { polymorphism was observed in HBV-infected individuals. }\end{array}$ \\
\hline
\end{tabular}

Note: HBV, hepatitis B virus; HCV, hepatitis C virus; HCC, hepatocellular carcinoma; mEH, microsomal epoxide hydrolase; AFB, aflatoxin B1; GST, glutathione-Stransferase; NR, not reported.

doi:10.1371/journal.pone.0057064.t004 
ethnicities. Kiyohara et al. [38] reported that frequency of the $\mathrm{mEH} 113 \mathrm{His}$ allele is greatest in the Asian population $(51.2 \%)$, intermediate in Caucasians (30-40\%), and lowest in African Americans (19.3\%). Analyzing populations different from those of Kiyohara et al., Pinarbasi and coworkers [28] also observed that the rate of homozygous His113His is greatest in the Asian population $(18-42 \%)$ and intermediate in the European population (about $10 \%$ ). These findings are consistent with our metaanalysis. In our analysis, the Chinese population had the highest frequency of His 1 13His: 35-56\% among HCC cases and 26-44\% among healthy individuals and individuals with other liver diseases. The frequencies of His113His in populations from the UK, Sudan, Italy, and India were 11-28\% among HCC cases and $7-29 \%$ among healthy individuals and individuals with other liver diseases. The frequency in the Gambian population was lowest at $5 \%$ (Table 1).

Our data revealed that His $113 \mathrm{His} \mathrm{mEH}$ is a risk factor for hepatocarcinogenesis, but the complete picture is more complex. Both China and Gambia have among the highest incidences of $\mathrm{HCC}$ in the world, as well as a high prevalence of HBV infection and dietary exposure to $\mathrm{AFB}$, which are the two main risk factors for HCG [39-41]. Nevertheless, Chinese had the highest frequency of His $113 \mathrm{His}$ in our meta-analysis, while Gambians had the lowest. This discrepancy indicates that hepatocarcinogenesis has a complex, multifactorial etiology. It may also reflect the possibility that $\mathrm{mEH}$ mitigates the carcinogenic effects of AFB [42]. Polymorphisms in numerous other genes, such as those encoding epidermal growth factor [43] and tumor necrosis factoralpha [44] are also associated with the risk of HCG. It may be that any single nucleotide polymorphism such as Hisl13His is insufficient on its own to cause HCC, though it does increase the risk of the disease.

Of the total number of 5,296 subjects considered in the metaanalysis, at least 2,000 (37.8\%) had one or more of the following: alcoholic liver disease, $\mathrm{HBV}$ or $\mathrm{HCV}$ infection, and cirrhosis. Since the studies in our meta-analysis often did not report detailed statistics on the proportion of HCC or control subjects with these background conditions, we could not perform subgroup analysis to separate the contribution of $\mathrm{mEH}$ polymorphism from that of possible confounders like HBV or HCV infection. Some other limitations of this meta-analysis also should be considered when interpreting the results. Bias may result from our exclusion of

\section{References}

1. Jemal A, Bray F, Genter MM, Ferlay J, Ward E, et al. (2011) Global cancer statistics. CA Cancer J Clin 61: 69-90.

2. Nordenstedt H, White DL, El-Serag HB (2010) The changing pattern of epidemiology in hepatocellular carcinoma. Dig Liver Dis 42 Suppl 3: S206-214.

3. Kirk GD, Lesi OA, Mendy M, Akano AO, Sam O, et al. (2004) The Gambia Liver Cancer Study: Infection with hepatitis B and $\mathrm{C}$ and the risk of hepatocellular carcinoma in West Africa. Hepatology 39: 211-219.

4. Velazquez RF, Rodriguez M, Navascues CA, Linares A, Pérez R, et al. (2003) Prospective analysis of risk factors for hepatocellular carcinoma in patients with liver cirrhosis. Hepatology 37: 520-527.

5. Coleman WB (2003) Mechanisms of human hepatocarcinogenesis. Curr Mol Med 3: 573-588.

6. Newman JW, Morisseau C, Hammock BD (2005) Epoxide hydrolases: their roles and interactions with lipid metabolism. Prog Lipid Res 44: 1-51.

7. Fretland AJ, Omiecinski CJ (2000) Epoxide hydrolases: biochemistry and molecular biology. Chem Biol Interact 129: 41-59.

8. Shou M, Gonzalez FJ, Gelboin HV (1996) Stereoselective epoxidation and hydration at the K-region of polycyclic aromatic hydrocarbons by cDNAexpressed cytochromes P450 1A1, 1A2, and epoxide hydrolase. Biochemistry 35: 15807-813.

9. Hassett C, Aicher L, Sidhu JS, Omiecinski CJ (1994) Human microsomal epoxide hydrolase: genetic polymorphism and functional expression in vitro of amino acid variants. Hum Mol Genet 3: 421-428.

10. McGlynn KA, Rosvold EA, Lustbader ED, Hu Y, Clapper ML, et al. (1995) Susceptibility to hepatocellular carcinoma is associated with genetic variation in unpublished data, as well as papers published in languages other than English and Chinese [45]. Second, the results may be affected by additional confounding factors, such as tumor status, age or gender, but most studies either did not report these baseline data or aggregated them in different ways, making it impossible to include them in the meta-analysis. Third, there was significant heterogeneity among the studies. Fourth, five studies were based on non-overlapping countries and ethnicities and relied on quite small samples. Fifth, the result in the allelic contrast was altered after excluding one study. Therefore, the result should be explained with caution. Moreover, the distribution of genotypes among controls did not show HWE in several studies.

In conclusion, this meta-analysis suggests that the His $113 \mathrm{His}$ $\mathrm{mEH}$ polymorphism may be associated with increased risk of $\mathrm{HCC}$, especially in the Chinese population. Moreover, the $\mathrm{mEH}$ gene is involved in synergistic gene-gene and gene-environment interactions. These results suggest that sequence variation in exon 3 of the $\mathrm{mEH}$ gene may play an important role in the occurrence of HCC. In contrast, no association was observed between $\mathrm{mEH}$ gene variation in exon 4 and the risk of HCC. However, since this meta-analysis included few studies from non-Asian populations, large, well-designed studies in Caucasian and African populations are warranted to re-evaluate these associations.

This meta-analysis is guided by the PRISMA statement (Checklist S1).

\section{Supporting Information}

Table S1 Overall and stratified meta-analyses of the association between $\mathrm{mEH}$ polymorphism His $139 \mathrm{Arg}$ and risk of hepatocellular carcinoma.

(DOG)

\section{Acknowledgments}

The authors thank Dr Armando Chapin Rodríguez for his language editing, which substantially improved the quality of the manuscript.

\section{Author Contributions}

Conceived and designed the experiments: JHZ LL. Performed the experiments: BDX GSX. Analyzed the data: LM XMY. Wrote the paper: JHZ BDX. the enzymatic detoxification of aflatoxin B1. Proc Natl Acad Sci U S A 92: $2384-2387$.

11. Shen F, Hu Y (1997) Association between the gene polymorphism of epoxide hydrolase and the susceptibility to primary hepatocellular carcinoma. Chin J Med Genet 14: 96-98.

12. Wong NA, Rae F, Bathgate A, Smith CA, Harrison DJ (2000) Polymorphisms of the gene for microsomal epoxide hydrolase and susceptibility to alcoholic liver disease and hepatocellular carcinoma in a Caucasian population. Toxicol Lett 115: $17-22$.

13. Tiemersma EW, Omer RE, Bunschoten A, van't Veer P, Kok FJ, et al. (2001) Role of genetic polymorphism of glutathione-S-transferase T1 and microsomal epoxide hydrolase in aflatoxin-associated hepatocellular carcinoma. Cancer Epidemiol Biomarkers Prev 10: 785-791.

14. Sonzogni L, Silvestri L, De Silvestri A, Gritti C, Foti L, et al. (2002) Polymorphisms of microsomal epoxide hydrolase gene and severity of HCVrelated liver disease. Hepatology 36: 195-201.

15. McGlynn KA, Hunter K, LeVoyer T, Roush J, Wise P, et al. (2003) Susceptibility to aflatoxin B1-related primary hepatocellular carcinoma in mice and humans. Cancer Res 63: 4594-4601.

16. Cao YY, Bian JC, Jiang F, Zhang ZM, Wang QM, et al. (2004) Association between the genetic polymorphism of epoxide hydrolase and the genetic susceptibility to primary liver cancer. Fudan University Journal of Medical Sciences 31: 363-367.

17. Kirk GD, Turner PC, Gong Y, Lesi OA, Mendy M, et al. (2005) Hepatocellular carcinoma and polymorphisms in carcinogen-metabolizing and DNA repair 
enzymes in a population with aflatoxin exposure and hepatitis B virus endemicity. Cancer Epidemiol Biomarkers Prev 14: 373-379.

18. Long XD, Ma Y, Wei YP, Deng ZL (2006) The polymorphisms of GSTM1, GSTT1, HYL1*2, and XRCC1, and aflatoxin B1-related hepatocellular carcinoma in Guangxi population, China. Hepatol Res 36: 48-55.

19. Kiran M, Chawla YK, Kaur J (2008) Glutathione-S-transferase and microsomal epoxide hydrolase polymorphism and viral-related hepatocellular carcinoma risk in India. DNA Cell Biol 27: 687-694.

20. He SJ, Gu YY, Lin WZ, Zeng XY, Liao ZH (2008) Polymorphism of microsomal epoxide hydrolase and susceptibility to primary hepatocellular carcinoma. Tumor 28: 125-128.

21. Higgins JP, Thompson SG, Deeks JJ, Altman DG (2003) Measuring inconsistency in meta-analyses. BMJ 327: 557-560.

22. Ioannidis JP, Trikalinos TA (2007) An exploratory test for an excess of significant findings. Clin Trials 4: 245-253.

23. Kiran M, Chawla YK, Jain M, Kaur J (2009) Haplotypes of microsomal epoxide hydrolase and x-ray cross-complementing group 1 genes in Indian hepatocellular carcinoma patients. DNA Cell Biol 28: 573-577.

24. Rahat B, Kiran M, Saxena R, Chawla YK, Sharma RR, et al. (2012) Microsomal Epoxide Hydrolase Polymorphisms and Haplotypes as Determinants of Hepatitis B Virusand Hepatitis C Virus-related Liver Disease in Indian Population. J Clin Exp Hepatol 2: 104-111.

25. Llovet JM, Bruix J (2008) Molecular targeted therapies in hepatocellular carcinoma. Hepatology 48: 1312-1327.

26. Koutros S, Andreotti G, Berndt SI, Hughes BK, Lubin JH, et al. (2011) Xenobiotic-metabolizing gene variants, pesticide use, and the risk of prostate cancer. Pharmacogenet Genomics 21: 615-623.

27. Goode EL, White KL, Vierkant RA, Phelan CM, Cunningham JM, et al. (2011) Xenobiotic-Metabolizing gene polymorphisms and ovarian cancer risk. Mol Carcinog 50: 397-402.

28. Pinarbasi H, Silig Y, Pinarbasi E (2010) Microsomal epoxide hydrolase polymorphisms. Mol Med Report 3: 723-727.

29. Ghattas MH, Amer MA (2012) Possible role of microsomal epoxide hydrolase gene polymorphism as a risk factor for developing insulin resistance and type 2 diabetes mellitus. Endocrine [Epub ahead of print].

30. Bhaskar LV, Thangaraj K, Patel M, Shah AM, Gopal K, et al. (2012) EPHX1 Gene Polymorphisms in Alcohol Dependence and their Distribution among the Indian Populations. Am J Drug Alcohol Abuse [Epub ahead of print].

31. Chen CZ, Wang RH, Lee CH, Lin CC, Chang HY, et al. (2011) Polymorphism of microsomal epoxide hydrolase is associated with chronic obstructive pulmonary disease and bronchodilator response. J Formos Med Assoc 110: 685-689.
32. Lee WJ, Brennan P, Boffetta P, London SJ, Benhamou S, et al. (2002) Microsomal epoxide hydrolase polymorphisms and lung cancer risk: a quantitative review. Biomarkers 7: 230-241.

33. Li X, Hu Z, Qu X, Zhu J, Li L, et al. (2011) Putative EPHX1 enzyme activity is related with risk of lung and upper aerodigestive tract cancers: a comprehensive meta-analysis. PLoS One 6: el4749.

34. Dura P, Bregitha CV, Te Morsche RH, Roelofs HM, Kristinsson JO, et al. (2012) EPHX1 polymorphisms do not modify esophageal carcinoma susceptibility in Dutch Caucasians. Oncol Rep 27: 1710-1716.

35. Nisa H, Budhathoki S, Morita M, Toyomura K, Nagano J, et al. (2012) Microsomal epoxide hydrolase polymorphisms, cigarette smoking, and risk of colorectal cancer: The Fukuoka Colorectal Cancer Study. Mol Carcinog [Epub ahead of print].

36. Zhao ZQ, Guan QK, Yang FY, Zhao P, Zhou B, et al. (2012) System review and metaanalysis of the relationships between five metabolic gene polymorphisms and colorectal adenoma risk. Tumour Biol 33(2): 523-535.

37. Baxter SW, Choong DY, Campbell IG (2002) Microsomal epoxide hydrolase polymorphism and susceptibility to ovarian cancer. Cancer Lett 177: 75-81.

38. Kiyohara C, Yoshimasu K, Takayama K, Nakanishi Y (2006) EPHX1 polymorphisms and the risk of lung cancer: a HuGE review. Epidemiology 17: 89-99.

39. Wild CP, Jiang YZ, Allen SJ, Jansen LA, Hall AJ, et al. (1990) Aflatoxin-albumin adducts in human sera from different regions of the world. Carcinogenesis 11 : 2271-2274.

40. Wild GP, Hudson GJ, Sabbioni G, Chapot B, Hall AJ, et al. (1992) Dietary intake of aflatoxins and the level of albumin-bound aflatoxin in peripheral blood in The Gambia, West Africa. Cancer Epidemiol Biomarkers Prev 1: 229-234.

41. Vall Mayans M, Hall AJ, Inskip HM, Chotard J, Lindsay SW, et al. (1990) Risk factors for transmission of hepatitis B virus to Gambian children. Lancet 336: 1107-1109.

42. Kelly EJ, Erickson KE, Sengstag C, Eaton DL (2002) Expression of human microsomal epoxide hydrolase in Saccharomyces cerevisiae reveals a functional role in aflatoxin $\mathrm{B} 1$ detoxification. Toxicol Sci 65: 35-42.

43. ZhongJH, You XM, Gong WF, Ma L, Zhang Y, et al. (2012) Epidermal growth factor gene polymorphism and risk of hepatocellular carcinoma: a meta-analysis. PLoS One 7: e32159.

44. Qin H, Liu B, Shi T, Liu Y, Sun Y, et al. (2010) Tumour necrosis factor-alpha polymorphisms and hepatocellular carcinoma: a meta-analysis. J Int Med Res 38: $760-768$.

45. Pan Z, Trikalinos TA, Kavvoura FK, Lau J, Ioannidis JP (2005) Local literature bias in genetic epidemiology: an empirical evaluation of the Chinese literature. PLoS Med 2: e334. 